\title{
Fire frequency, fire seasonality and fire intensity within the Okavango region derived from MODIS fire products
}

\author{
Marion Stellmes, David Frantz, Manfred Finckh, Rasmus Revermann, Achim Röder \& \\ Joachim Hill
}

\begin{abstract}
The analysis and evaluation of ecosystems in the Okavango region must include a thorough analysis of the fire regime. This requires a full understanding of its components such as fire frequency, fire season and fire intensity. For the Okavango region these components were derived based on an extensive multi-scale compilation of the MODIS products "Active Fire" (AF) and "Burned Area" (BA) covering the period 2001 to 2012. The integrated analysis of these mutually exclusive datasets allowed for a comprehensive characterisation of important descriptors of the large scale fire regime. The descriptive fire parameters are discussed considering dominant land cover classes. These were derived by clustering phenological metrics which were in turn derived by analysing temporally dense MODIS time series of the Enhanced Vegetation Index (EVI).The variation within the study area regarding the overall area affected by fire, the fire frequency as well as the fire seasonality can be explained to a high degree by land cover and local human fire management practises. Thus, Miombo woodlands are less affected by fires than other vegetation communities like for instance thornbush savannahs or grasslands in the river valleys of the upper catchment.We provide a considerable overview of spatial and temporal fire dynamics within the Okavango region. This is an important step in generating the necessary information required to feed into land use management scenarios.
\end{abstract}

Keywords: active fire; burned area; fire frequency; fire intensity; fire seasonality.

Frequência, sazonalidade e intensidade de incêndio na região do Okavango, derivados de produtos de incêndio MODIS

Resumo: A análise e avaliação dos ecossistemas na região do Okavango têm de incluir uma análise aprofundada do sistema de incêndio, o que requer absoluto entendimento em relação aos seus componentes tais como, frequência, sazonalidade e intensidade de incêndio. Para a região do Okavango, estes componentes foram obtidos com base em uma extensa compilação em multiescala dos produtos MODIS AF (incêndio ativo) e BA (área queimada), cobrindo o período entre 2001 e 2012. A análise integrada destes conjuntos de dados, mutuamente exclusivos, permitiu uma caracterização mais completa de descritores importantes do regime de incêndio em grande escala. Os parâmetros de incêndio descritivos são discutidos, considerando as classes dominantes de cobertura do solo. Estes foram obtidos por meio de agrupamento de métricas fenológicas que foram, por sua vez, derivadas através da análise de séries temporais MODIS, temporalmente densas, do EVI (Índice de Vegetação Reforçada). A variação na área de estudo com relação à área total de estudo afetada por incêndio, pela sua frequência e também pela sua sazonalidade pode ser explicada, em um grau elevado, pela cobertura do solo e práticas locais de uso do fogo pelo homem. Assim, as florestas Miombo são menos afetadas por incêndios do que outras comunidades vegetais, como por exemplo, as savanas de espinheiro ou pastagens nos vales do rio da bacia superior. Fornecemos uma visão geral considerável da dinâmica espacial e temporal de incêndio na região do Okavango. Este é um passo importante para gerar informações necessárias aos cenários de gestão de uso do solo.

Palavras-chave: área queimada; frequência de incêndio; incêndio; intensidade de incêndio; sazonalidade de incêndio.

Received: 06 September 2013 - Accepted: 25 November 2013

\section{Introduction}

The assessment and evaluation of ecosystems in regions like the Okavango Catchment need a full understanding of the status, variability and change of land cover and land use systems. Wild fires are an important component in African landscape ecology and are even vital for the maintenance, distribution and function of fire-prone savannah ecosystems (Bond \& Keeley 2005). Therefore, it is indispensable to understand and describe the fire regime (van Langevelde et al. 2003).
Fire serves as a tool for humans. It is used to aid cultivation, e.g. in slash and burn agriculture, in hunting, honey collection, charcoal production or pest control. Moreover, farmers burn grasslands to induce fresh growth to provide fodder for cattle. Many of the fires in woodland systems of Southern Africa have their origin in these practices (Chidumayo 1995). Thus, most of the fires in Northern and Southern Africa are thought to be anthropogenic (Roy et al. 2008). These have been a part of the land use system for millennia (Clark \& Van Zinderen Bakker 1964) and ecosystems have adapted to them

Changing boundary conditions, e.g. decreasing rainfall amount and/or land use change related to population growth, may have major implications for the fire regime and in consequence on ecosystems functioning and the provision of ecosystem services (ESS). Increasing fire frequency may cause land degradation and the loss of biodiversity as the fire regime has a profound impact on species composition and vegetation structure (Anderson et al. 2003, Govender et al. 2006, Laris 2005; Trapnell 1959). For example, fire does 
have a severe impact on nutrient cycling, especially carbon and nitrogen are lost to the atmosphere (Giardina et al. 2000) Thus, almost one third of the global gross carbon dioxide emissions released by fires is attributed to fires of African savannahs (Andrae 1997, Sá et al. 2005).

The fire regime in African savannahs has been subject of numerous studies. Thereby, major objectives are the description and understanding of the fire regime in its variability and complexity, the understanding of its implications for ecosystem properties and the identification of the main drivers. Extensive scientific publications focussing on the fire regime in Namibia and Southern Africa are for instance provided by le Roux (2011) and Archibald (2010). Both authors focus on the use of remote sensing, GIS and modelling techniques to describe and explain the fire regime.

Remote sensing data are of major importance as they allow deriving key parameters that describe the fire regime both spatially and temporally. Currently, the MODIS (Moderate Resolution Imaging Spectroradiometer) sensor onboard the spacecrafts Terra and Aqua is unique in terms of global fire monitoring capabilities (Justice et al. 2006). At the moment, two entirely distinct fire-related products are developed, maintained, processed and distributed at no cost through the National Aeronautics and Space Administration (NASA) Land Processes Distributed Active Archive Center (LP DAAC) at the U.S. Geological Survey (USGS) Earth Resources Observation and Science (EROS) Center and its affiliates. The Active Fire (AF) product provides up to daily information at $1 \mathrm{~km}$ spatial resolution about thermal anomalies and their associated emitted energy, expressed as Fire Radiative Power (FRP) in megawatt (MW), which can be directly related to greenhouse gas emissions (Ichoku \& Kaufman 2005). The Burned Area (BA) product supplies the areal extent of burned areas with a spatial resolution of about $500 \mathrm{~m}$ by the detection of burn scars.

The key parameters that describe the fire regime are fire type, frequency, seasonality, and intensity whereby fire intensity is largely determined by fuel load and its heat yield as well as fire spread (le Roux 2011). The fire type refers to the vertical level of fire propagation, i.e. ground, surface or crown fires. The latter component was not considered in this study as crown fires are known to be rare (le Roux, 2011) and type information is not readily available from the chosen datasets. Thus, the objectives of this study were

1. to describe the fire regime in the Okavango Catchment regarding fire frequency, fire season and fire intensity covering the period 2001 until 2012

2. to understand the spatial patterns of the three fire regime descriptors by relating these parameters to land cover information.

\section{Data and methodology}

In this study we used two MODIS fire data sets. The two products AF and BA are based on entirely different methodologies and thus, interpretations of the results need to carefully consider this.

The AF product mainly utilizes brightness temperatures acquired through the thermal bands centred at $4 \mu \mathrm{m}$ and $11 \mu \mathrm{m}$ - regardless of day or night time. The MODIS sensors onboard Terra and Aqua capture the earth's surface of a given location on average four times a day. Daily information can be generated if at least one of the observations is available. Active fires or rather thermal anomalies are ultimately detected by relating brightness temperatures of a given pixel to the background value of its surrounding pixels (Justice et al. 2006). In case of daytime observations, additional tests employing visible and near infrared reflectances at $0.65 \mu \mathrm{m}$, $0.86 \mu \mathrm{m}$ and $2.1 \mu \mathrm{m}$ are used to reject false alarms, which are particularly caused by sun glints and water-induced false detections in case the MODIS land/sea mask contains errors. The latter test is known to reject some smaller fires (Giglio et al. 2003).

If ideal detection conditions are apparent, the smallest active fire that can be detected in $50 \%$ of all cases is $100 \mathrm{~m}^{2}$ (Giglio et al. 2003). Off-Nadir pointing, heterogeneity of the land surface (particularly if water or desert edges are situated within the vicinity of the pixel), contamination of the background signal (i.e. the neighbouring pixels of a candidate fire pixel) with fire, clouds, heavy smoke or sun glints can increase the minimal size substantially. In case of smouldering fires, the burning area within one pixel has to be 10 to 20 times larger. Crown fires may be smaller than $100 \mathrm{~m}^{2}$ (Giglio et al. 2003, Maier et al. 2013).

Therefore, the AF product can be classified as a snapshot-like data product which records the progression of the active fire line. If a fire moves too fast to be detected in two adjacent pixels between two overpasses, a gap occurs. If a fire is not active or obscured by heavy smoke or clouds at overpass, it is not picked up either. Short duration fires might be also missed if not at overpass time. Thus, $\mathrm{AF}$ products are inadequate if total burned area is wished to derive (Pereira et al. 2003), but are superior in rapid mapping applications (Davies et al. 2009). They are also a valuable alternative in estimating consumed biomass and its emissions directly from FRP (e.g. Ichoku \& Kaufman 2005, Wooster et al. 2005, Vermote et al. 2009) instead of using the IPCC good practice methodology (Penman et al. 2003) with yet unsolved problems and uncertainties in operationally deriving nation-wide emission factors (De Sy et al. 2012). Contrary, burned areas are derived by applying a bi-directional reflectance function (BRDF) model-based change detection algorithm on basis of daytimeonly reflectance data (Roy et al. 2002; Roy et al. 2005a). Reflectances that were acquired over a period of weeks to months with a maximum of one valid observation per day (Roy et al. 2005a) are used to predict the next observation. A burned area is detected if the observed and predicted value differs significantly and if the nature of change matches the characteristics of burning (Justice et al. 2006).

An inversion of the BRDF model can only be attempted if at least 7 clear observations are available. All cloudy, snow, high aerosol, non-land, high solar or view zenith angles $\left(>65^{\circ}\right)$ or bad quality data are excluded (Justice et al. 2006). Thus, the derivation of the BA product is in demand of persistently high quality data and any prolonged period of data absence causes the algorithm to fail.

The temporal sampling problem of $\mathrm{AF}$ detection is uncritical in $\mathrm{BA}$ detection as the burn-induced spectral change is quite persistent over time (Roy et al. 2002). On the one hand, the fire event has not to be recorded at overpass time, on the other hand the spectral response in African savannahs is highly transient with a short spectral recovery time of about one month (Pereira 2003). Thus, if there was a prolonged period of data unavailability 


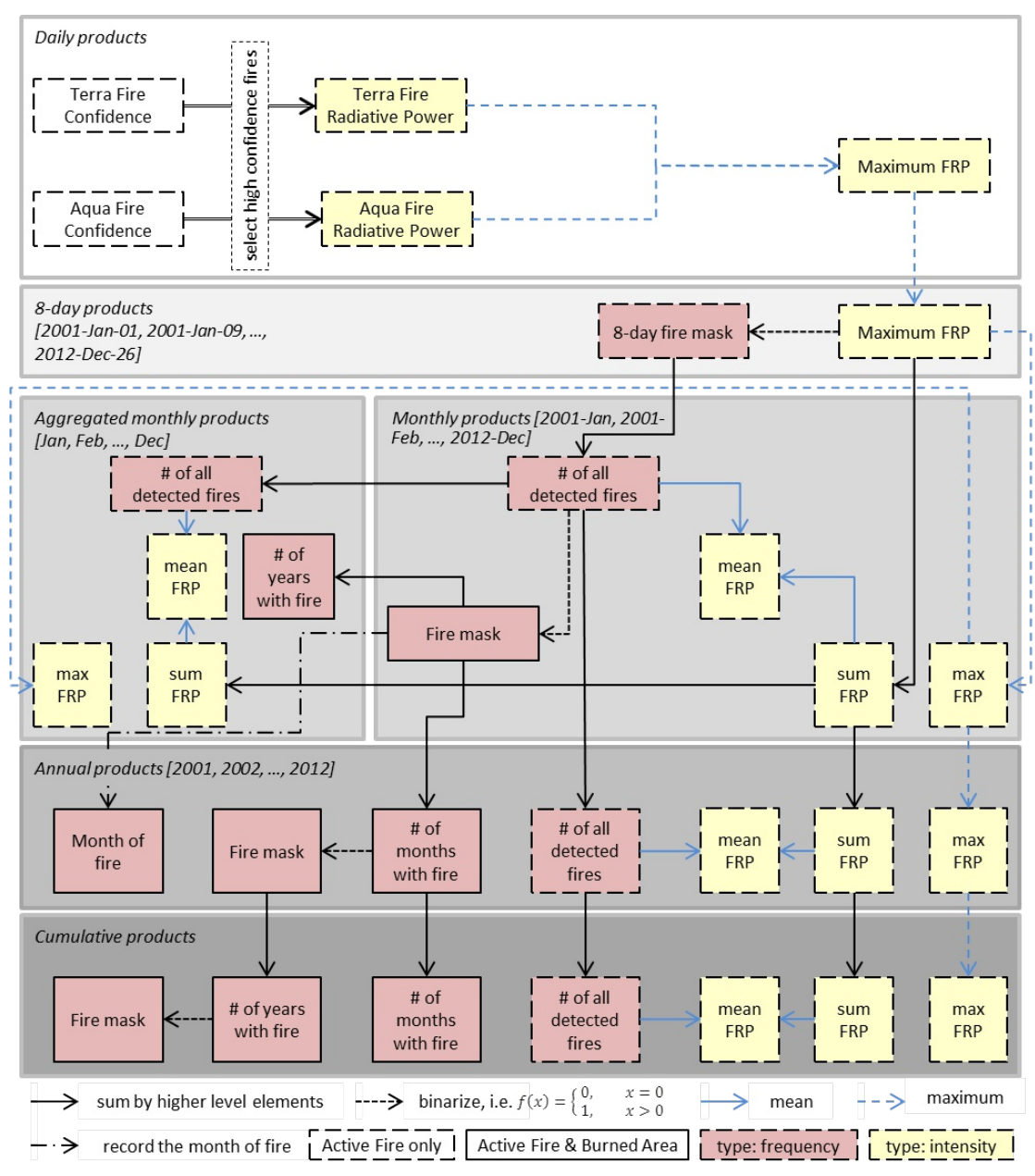

Fig. 1: Flowchart of the implemented analysis scheme.

burned areas might still be missed.

Snow melt, vegetation removal over less reflective soils, flooding, vegetation senescence or shadows may be confused with burning as the spectral change is similar (Roy et al. 2005a) or might be induced by residual cloud or shadow contamination (Roy et al. 2002). Although the algorithm incorporates several tests to minimize false detections, a certain amount of commission errors might still be apparent. In addition, fires might be missed in case of very hot fires that produce highly reflective white ash, which rather increases than decreases reflectance after the fire (Stronach \& McNaughton, 1989). Several studies indicate that understorey burns are still detectable in remotely sensed imagery if tree cover density is below $60 \%$ (Fuller et al. 1997, Pereira, 2003) and might even remain detectable above (Pereira, 2003).

The smallest reliably detectable burned areas are larger than $1 \mathrm{~km}^{2}$ (Roy et al. 2005b). Therefore, despite the higher geometric resolution of $\mathrm{BA}, \mathrm{AF}$ can detect smaller fires if they are sufficiently year. The top-level products are cumulated for the entire period, yielding only one layer of data for the observation period.

Two different thematic products were derived, namely fire frequency (number of fires per aggregation period, depicted as red boxes) and fire intensity products (based on FRP, depicted as yellow boxes).

Products which were computed for $\mathrm{AF}$ and $\mathrm{BA}$ are drawn in solid boxes, whereas products that were only derived for $\mathrm{AF}$ are drawn in dashed boxes. The different aggregation methods are depicted as arrows of different line type and colour.

\section{Active Fire (AF)}

The daily AF products of Terra and Aqua (MOD14A1 and MYD14A1) were acquired from the LP DAAC EROS Center. Each image between January 2001 and December 2012 was obtained. Scenes that were collected in 2000 and 2013 were not processed because fractional years could potentially introduce a bias in the fire seasonality metrics. Moreover, MODIS data before November 2000 are considered untrustworthy because of frequent detector outages (Giglio 2010).

The individual tiles were mosaicked by employing the MODIS Reprojection Tool (MRT; Dwyer et al. 2001), which was developed by the LP DAAC and the South Dakota School of Mines \& Technology. The mosaicked files were reprojected with MRT to a geographic grid $\left(\right.$ Datum $=$ WGS 84 ) with $0.009^{\circ}$ pixel spacing using nearest neighbour resampling.

\section{Fire Radiative Power (FRP)}

On a daily basis, the maximum FRP of the fires detected by MODIS onboard Terra and Aqua with high confidence was recorded. Less confident fires were excluded because the nominal confidence class contains highly questionable pixels (Giglio 2010). The daily FRP images were aggregated to 8-day FRP composites, matching the temporal characteristics of the nominal 8-day MODIS products. The maximum FRP of all the daily images within one 8-day period was used as aggregation criterion (depicted as blue dashed arrows in Figure 1 ), because it was assumed that if there were several fires per pixel in one 8-day period, these fires were rather one longlasting fire. In order to avoid a bias in high values of the FRP when slow 


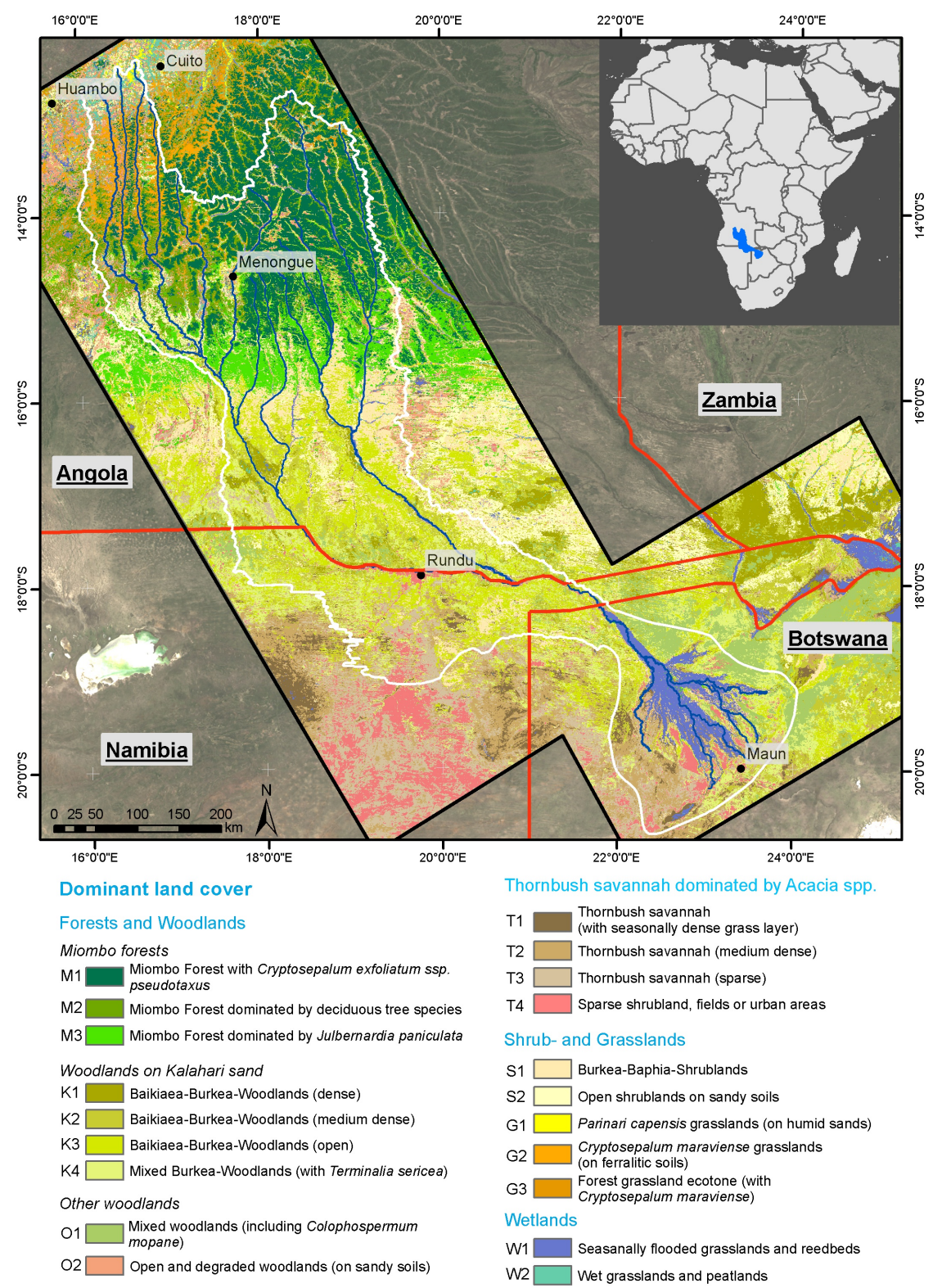

Additional information Okavango Catchment

$\diamond$ Analysis frame FORA $\sim \sim$ Country boundaries $\sim$ Main rivers

Data source/background:

The classfication is based on phenology parameters that were derived with the software package TIMESAT (Jönsson and Eklundh 2002) based on the MODIS 16-day EVI product (MOD1301) courtesy of EOSDIS-NASA. Country boundaries courtesy of ESRI (Data and Maps).

Fig. 2: Map of major land cover strata within the Okavango Catchment as derived from MODIS 16-day EVI composites (2000-2011). The white line depicts the Future Okavango Research Area (FORA), which represents the study area of the project "The Future Okavango" (TFO).

moving fire lines (i.e. $<1 \mathrm{~km} /$ day) are present, summation was not started until the creation of the 8-day composites (indicated by black solid arrows). Slow moving fires are likely to be rather cool fires (le Roux 2011) and if the individual images were simply cumulated, these cool fires would dissemble hotter fires.

For each 8-day period, a fire mask was generated (indicated by black dashed arrows in Figure 1 and denoted as binarized), which indicates if there was a
The derived monthly products were aggregated in a similar way to generate the annual products: the monthly fire frequencies were summed up for each year, yielding the annual fire frequency. The aggregation of the monthly fire masks resulted in an annual fire frequency on basis of the months, i.e. the number of months with a detected fire per year. Again, annual fire masks were created, which indicate whether a fire occurred in a given year or not. The month of fire product is a special product as it does not conform to the general aggregation strategy. It contains information about the month a fire was detected and is a very useful product when analysis or visualization of the main fire season is desired.

The top-level products were obtained by summing up the annual products, yielding fire products representative for the whole period of MODIS operation under investigation (2001 to 2012): a product with the total number of detected fires, a product with the number of months with fire and a product with the number of years with fire was generated. An overall fire mask was also created stating whether a pixel was burnt at all within the 12-year period or not.

As the spatial spattern of fire seasonality was of special interest, another product line was generated on basis of the monthly products. A product with the total number of fires per month (e.g. September) and a product with the number of years with fire per month (e.g. September) was derived. This product provides information about how often a fire occurred in a specific month, e.g. the number of fire-prone years in September.

Finally, the maximum, sum and mean of FRP were derived for each aggregation level. Figure 1 depicts a flowchart of the various aggregation stages for clarity.

\section{Invalid observations}

8-day quality masks were generated by identifying pixels with invalid observations, i.e. if both Terra and Aqua observations were indicated as erroneous based on the information provided with the data product. A valid observation was considered as being a fire (regardless of detection confidence) or non-fire clear land. Consequently, an observation was considered invalid in terms of fire detection if the pixel was classified as water, cloud or if it was not processed due to lacking data. Quality products were generated for every aggregation level, in each case giving the percentage of invalid observations. 


\section{Burned Area (BA)}

\section{Fire frequency}

The pre-processed BA product which is compiled and distributed by the University of Maryland was employed for BA detection. The product is based on the MCD45 product and provides information at a spatial resolution of about $500 \mathrm{~m}$ on a monthly basis whereby the product includes also information about the probable date of fire occurrence. The processing flow follows the procedure outlined above, only differing in the entry stage. The basis for aggregation is a monthly BA mask. The products which are based on the lowerlevel 8-day fire mask were not derived for the BA product suite, nor was FRP (only solid boxes in Fig. 1).

The monthly BA mask was compiled by identifying pixels with confidence levels 1 and 2, which represent the most confident detections. The confidence of detected fires was derived from a Quality Assurance layer (QA) that is provided with the data set.

\section{Invalid observations}

Similar to the AF product, a quality mask was generated for each basis file and was afterwards aggregated to the higher levels in terms of percentage of invalid observations within the observation period. Based on the information provided with the dataset, a valid pixel was considered as burned or unburned land while an invalid observation was considered if one of the following states or land cover classes was apparent: water, cloud, snow, high aerosol, no or not enough data to perform the BRDF inversion.

\section{Land cover information}

The fire products were analysed and interpreted by intersecting them with land cover information. This was done to judge the reliability of the results, to compare the spatial and temporal patterns with findings from other studies and finally, to explain and understand the fire regime in the Okavango Catchment.

Land cover provides valuable information for interpreting fire products (Fig. 2). We used land cover information derived from MODIS Terra time series of the vegetation index product (MOD13Q1) provided by EOSDIS/NASA. The Enhanced Vegetation Index (EVI) is related to vegetation density and cover (Huete et al. 2002). The product consists of 16-day composites with a spatial resolution of
$250 \mathrm{~m}$ and is available since April 2000. Due to the high temporal resolution the product captures the development of vegetation cover within a year and therefore, enables the derivation of information describing the phenology of vegetation cover.

Phenology metrics were calculated for the period 2001 to 2012 using the software TIMESAT (Jönsson \& Eklundh 2002). Because different vegetation communities differ in their phenological characteristics, these parameters can be employed to discriminate major land cover types. We chose six parameters to derive major land cover types (compare also electronic Appendix of Catchment Factsheet A):

$i$ the start of the vegetation period;

ii the mean base value (the minimum EVI value which can be related to standing biomass);

iii the mean large integral (integral of the annual EVI curve, which can be related to overall biomass);

iv the mean amplitude (range between minimum and maximum EVI value, which provides information about the strength of the
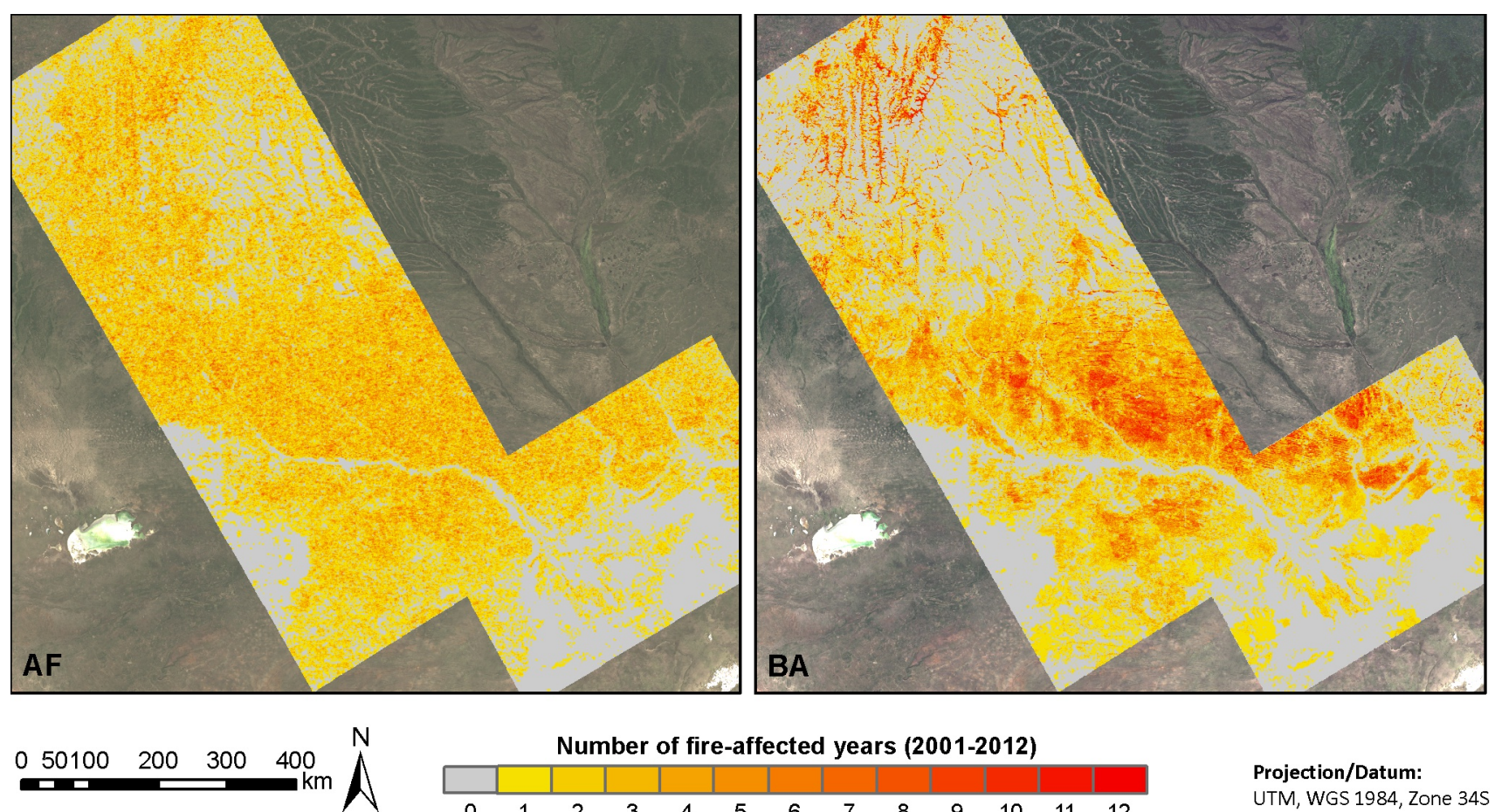

Number of fire-affected years (2001-2012)

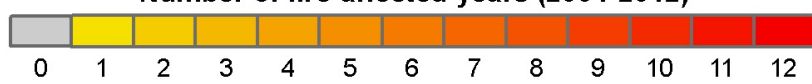

Projection/Datum

UTM, WGS 1984, Zone 345

Data source/background:

The datasets are based on the MODIS active fire product (MOD14A1 and MYD14A1) and the MODIS burned area product (MCD45A).

The background of the maps are MODIS reflectance images. All products courtesy of EOSDIS (NASA) and the University of Maryland.

Fig. 3: Number of fires per years detected with the AF product (left) and the BA product (right) in the period 2001 to 2012. 

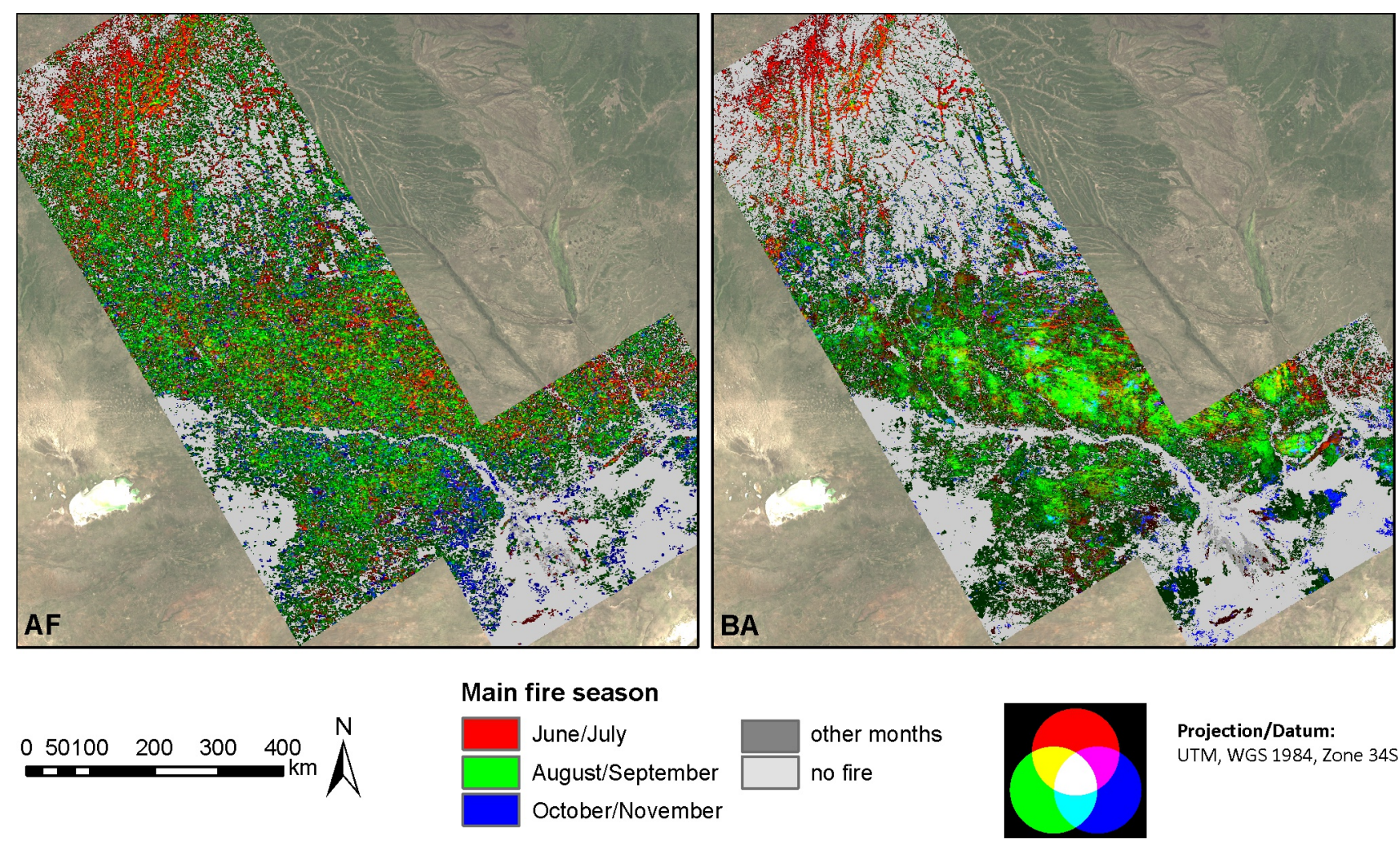

Projection/Datum:

UTM, WGS 1984, Zone 345

\section{Data source/background:}

The datasets are based on the MODIS active fire product (MOD14A1 and MYD14A1) and the MODIS burned area product (MCD45A).

The background of the maps are MODIS reflectance images. All data courtesy of EOSDIS (NASA) und the University of Maryland.

Figure 4: Main fire season derived from the AF product (left) and the BA product (right) in the period 2001 to 2012.

seasonality);

$\mathrm{v}$ mean Near Infrared (NIR) reflectance;

vi standard deviation of the NIR reflectance (both NIR parameters support the discrimination of aquatic ecosystems).

Based on this information major land cover strata within the Okavango Catchment were statistically distinguished by employing an unsupervised clustering algorithm (ISODATA) where pixels that are characterised by similar phenological properties will be summarized in one class. The nomenclature of the resulting 20 classes was developed based on extensive field work in the Okavango region and aims at identifying the dominant vegetation type that each class represents. This fact, as well as the spatial resolution of MODIS and the limited number of 20 classes, entail the potential shortcoming that the actual vegetation cover might locally differ from the nomenclature in the map.

The land cover map (Fig. 2) shows a gradient in land cover classes from the upper catchment with high rainfall amounts compared to the downstream areas. The northern part of the catchment is dominated by Miombo woodlands. These woodlands are traversed by river valleys feeding the tributaries of the Okavango River. Open grasslands dominate these valleys. The middle reaches are characterized by extensive woodlands on Kalahari sand. The Delta area with low precipitation is surrounded by mixed woodlands on the Eastern side, whereas on the Western side thornbush savannah represents the main vegetation type. The Okavango Panhandle and Delta form a special ecosystem that is characterised by inundation seasonality.

\section{Results and discussion}

\section{Fire frequency}

Figure 3 shows the number of years fires were detected by the $\mathrm{AF}$ and $\mathrm{BA}$ product within the observation period (2001 to 2012). The two maps are consistent regarding their overall pattern of areas that are affected or non-affected by fire events. Most areas of the catchment have experienced fires except for some parts in the north-eastern and south-western catchment as well as south of the Okavango Delta. Thereby, fire frequency is very heterogonous across the Okavango Catchment according to both MODIS products. However, the BA product shows a more structured picture of the overall number of years with detected fires whereas the structure of the AF map resembles a discontinuous pattern. The reason for this can be attributed to the different fire detection algorithms. The AF product is based on snap-shots in time which deliver information about actual fire fronts and their intensity whereas the BA product detects the change of spectral surface properties due to fire events, i.e. the burning of fuel (e.g. dry vegetation) and the remaining fire residues (e.g. ash). Hence, the AF product provides rather point information whereas the BA product delivers areal information. For this reason, the BA product can be regarded as more reliable concerning the detected number of fires. According to the BA map, areas affected by a very high frequency of fires are located in the border region of Namibia and Angola and the river valleys of the upper catchment area. 


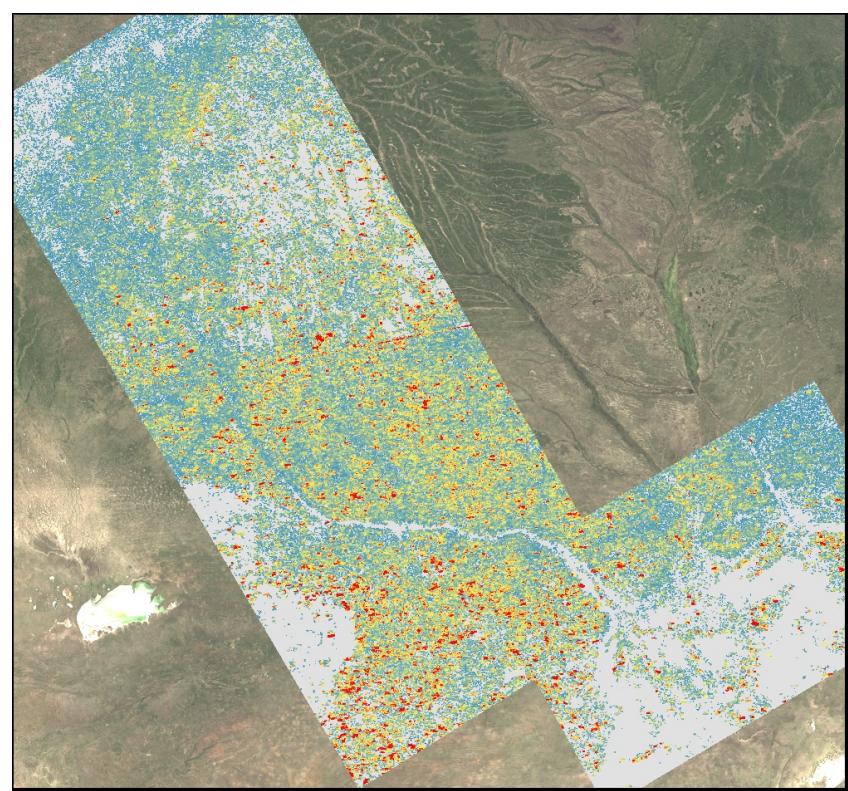

Mean fire radiative power in $\mathrm{MW}$

0

no fire

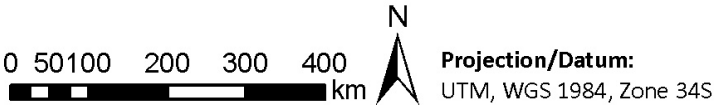

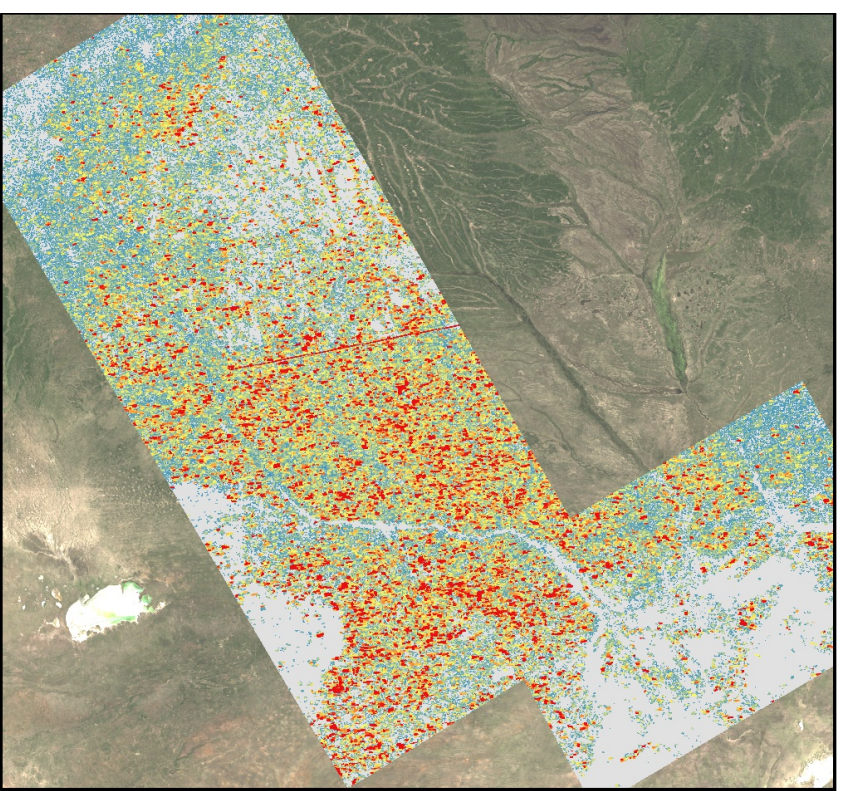

Maximum fire radiative power in MW

0

$>500$

\section{Data source/background:}

The datasets are based on the MODIS active fire product (MOD14A1 and MYD14A1). Left: mean FRP. Right: maximum FRP.

The background of the maps are MODIS reflectance images.

All data courtesy of EOSDIS (NASA).

Fig. 5: Mean (left) and maximum (right) FRP of the fires derived from the AF product in the period 2001 to 2012 . The range of FRP is much higher than indicated in the colour bar (mean up to $700 \mathrm{MW}$; maximum up to $1200 \mathrm{MW}$ ). The colour bar was chosen to amplify the visual separability of low intensity values.
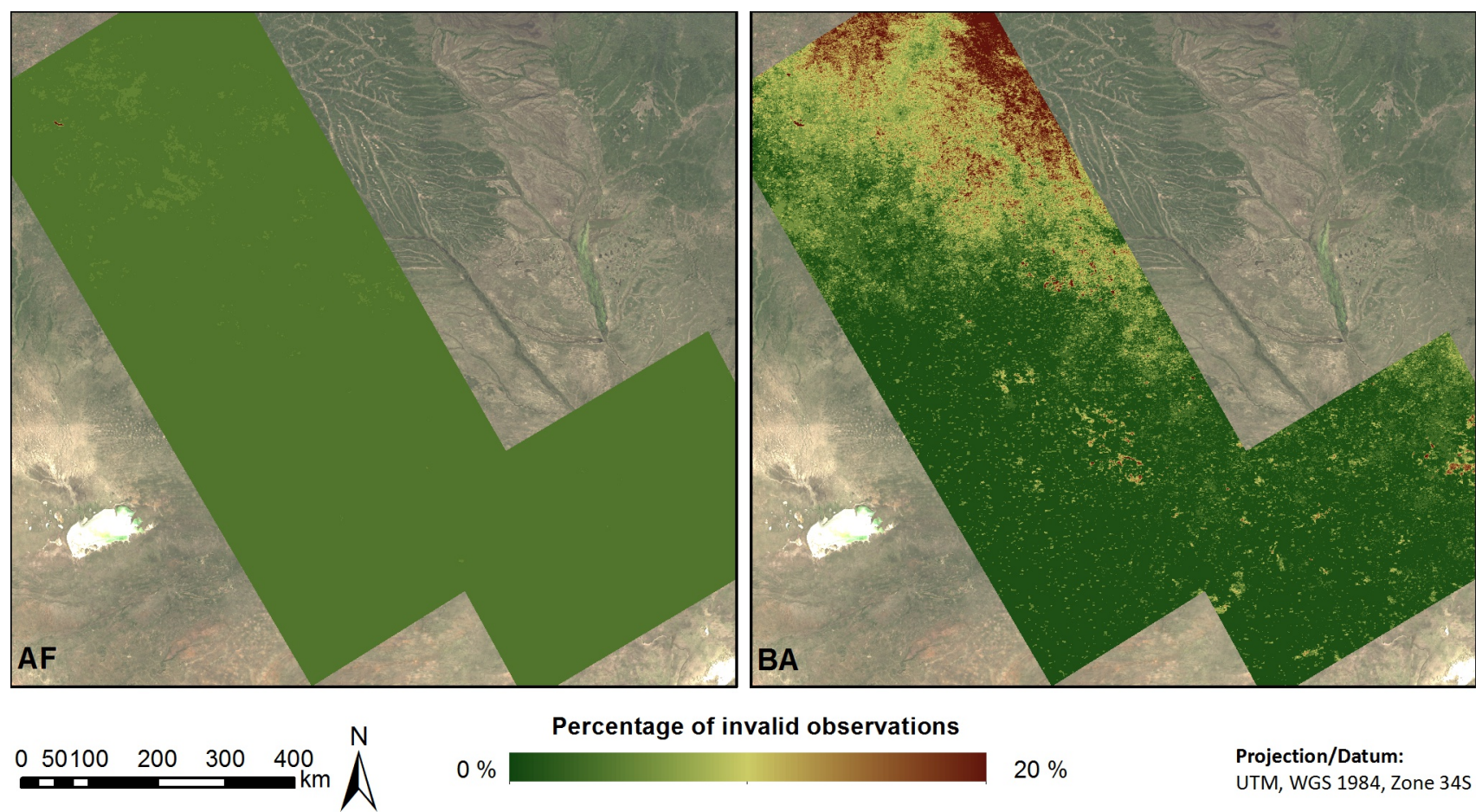

Percentage of invalid observations

$0 \%$

Projection/Datum:

UTM, WGS 1984, Zone 34 S

Data source/background:

The datasets are based on the MODIS active fire product (MOD14A1 and MYD14A1) and the MODIS burned area product (MCD45A).

The background of the maps are MODIS reflectance images. The products are provided by EOSDIS (NASA) und the University of Maryland.

Fig. 6: Overall percentage of invalid observations of the AF product (left) and the BA product (right). 


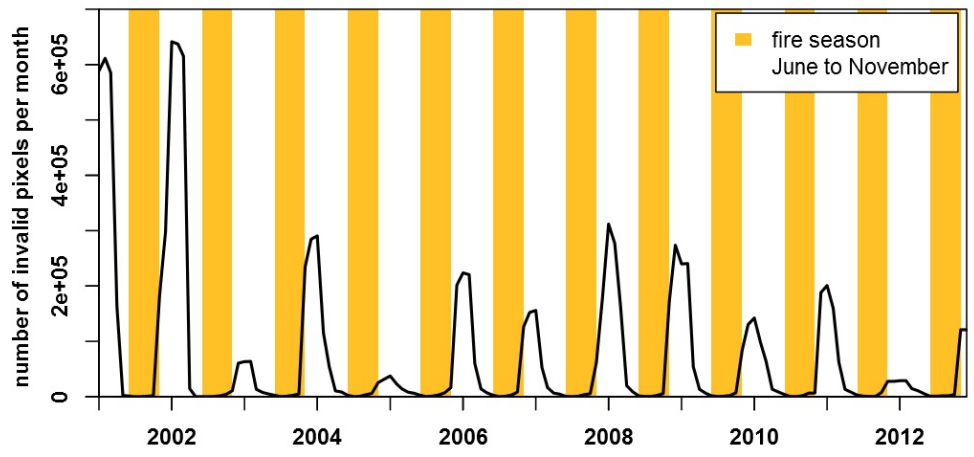

Fig. 7: Number of invalid BA pixels per month. The fire season as depicted in Figure 4 is displayed in yellow bars.

\section{Fire seasonality}

Overall, the fire season in the study area starts in May and ends in October in accordance with the dry season. The main fire season is represented as a false colour RGB-composite (Fig. 4) where red colour corresponds to a main fire season in June/July, green colour in August/September and blue colour in October/November. Colour mixtures like
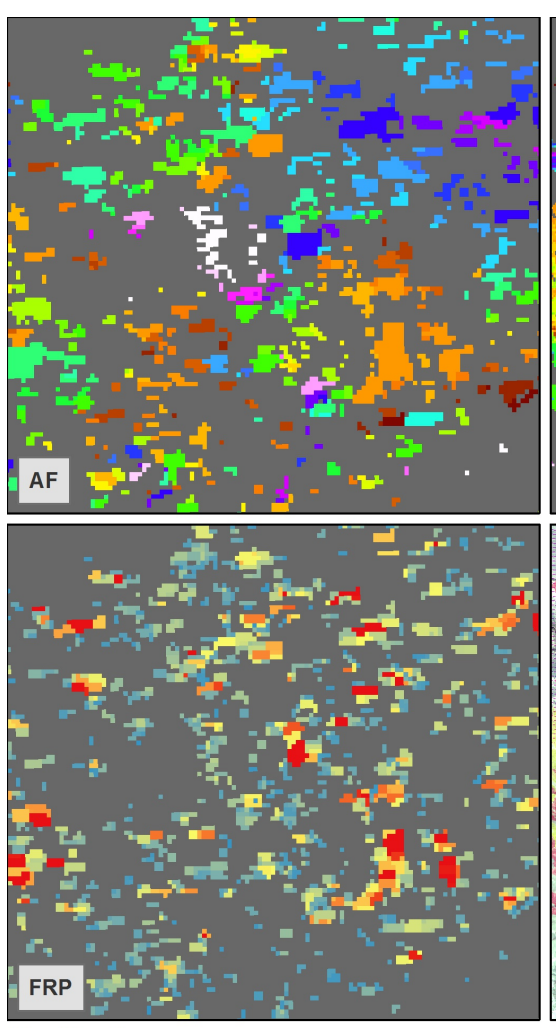

Day of burning

01.09 .2008

30.09 .2008

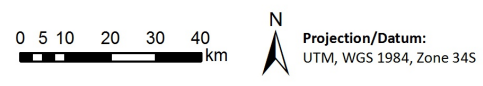

for instance yellow (mixture of green and red) and cyan (mixture of green and blue) indicate that the fire period lasts from June to September or August to November, respectively. The brightness of the colours is related to the fire frequency. The map clearly illustrates that the main fire season spatially varies within the Okavango Catchment.

In the upper catchment fires in the river valleys are mainly occurring in June and
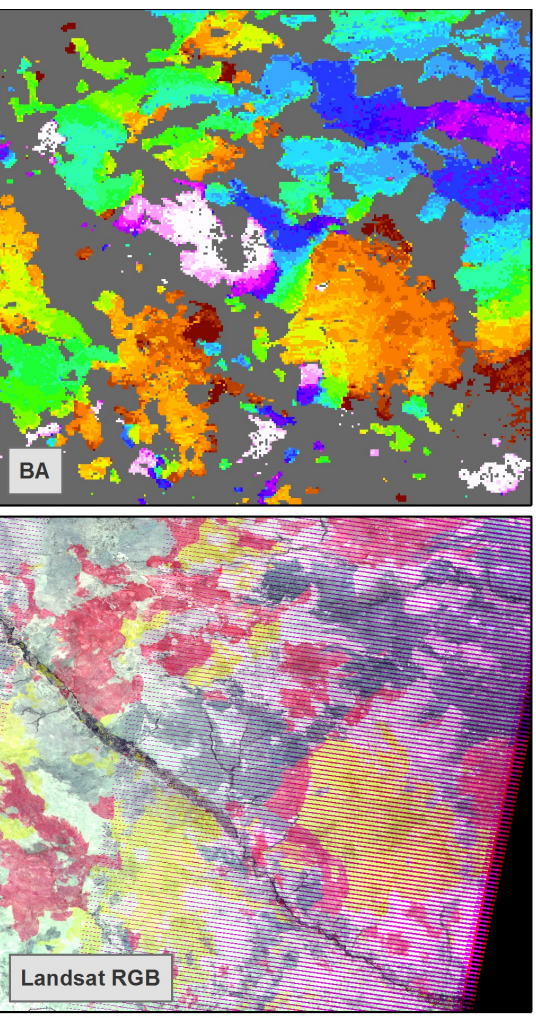

Maximum fire radiative power in MW

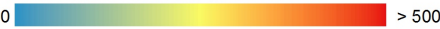

Data source/background:

The datasets are based on the MODIS active fire product (MOD14A1 an MYD14A1) and the MODIS burned area product (MCD45A). The products are provided by EOSDIS (NASA) and the University of Maryland.
Landsat TM/ETM+ data are provided by the USGS.

July, whereas the fires in the Angolan/Namibian border region are mainly found in August and September but may also occur earlier or later. Fires in October and November are mainly observed in the north eastern area where fire frequency is rather low. It is remarkable that fires do not occur in areas that are densely populated which might result from the agricultural system where fields are almost bare during the dry season. Agricultural fires might be too small to be detected by MODIS, though AF is generally able to detect small-scale agricultural fires (Roy et al. 2008, Korontzi et al. 2006). Contrary, short duration burns on agricultural fields that are immediately ploughed, may not be detected (Roy et al. 2008). This is especially true for $\mathrm{BA}$ as the $\mathrm{BA}$ algorithm depends on a lasting spectral change and the minimal required burned area is larger than for AF.

\section{Fire intensity}

Fire intensity is a very important factor to describe the fire regime and was derived from the daily AF products as described in the data and methodology section. Figure 5 illustrates the mean FRP per pixel (left) and the maximum FRP (right) that was registered within the observation period. Mean and maximum FRP are both distributed very heterogeneous and patchy within the study area. Only the northern and eastern regions show lower FRP values compared to the other areas of the study region. In the central part of the Fig., there is a striking straight red line, which is caused by night-time false detections of MODIS Terra on 2010/04/14 with high FRP values. The effect on class statistics as presented in Figure 13 is expected to be minor, as the overall per class area is high compared to the intersecting size of the artefact.

Even though the AF product may have drawbacks in monitoring areal extent, information concerning fire intensity of individual fires might be regarded as reliable as fire intensity is directly quantified from radiated energy.

\section{Influence of invalid observations on fire detection}

A high amount of invalid observations may reduce the reliability of the information derived from the MODIS fire products. Figure 6 clearly illustrates that for $\mathrm{AF}$ there is a very low percentage of 


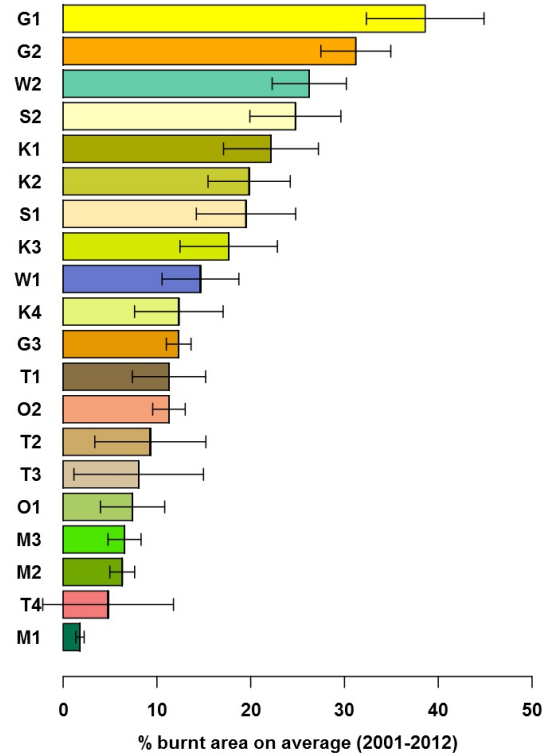

Fig. 9: Mean annual percentage of fire affected areas within each major land cover class within the observation period 2001 to 2012.

invalid observations. In contrast, BA shows a high proportion of invalid observations in the north eastern parts of the study area amounting to up to $20 \%$. This distribution of invalid observations in BA clearly resembles the major climatic zones of the catchment with a north-south gradient in precipitation. The comparison of the patterns of the invalid observations among $\mathrm{AF}$ and $\mathrm{BA}$ reflects the different methodologies and their distinct demand for data availability. The probability for a clear AF observation within an 8-day period is rather high when considering the on average four MODIS acquisitions per day. The methodology of the BA product is quite

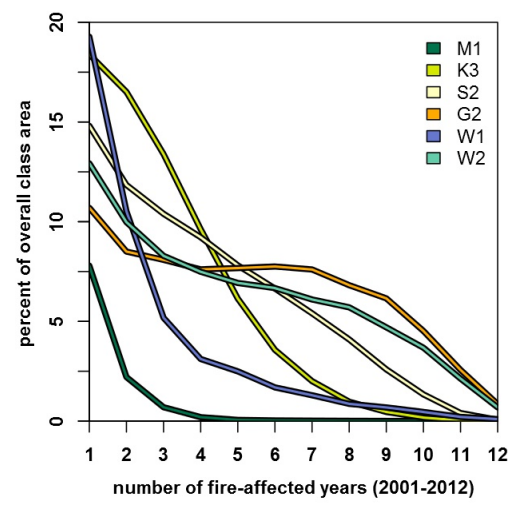

Fig. 11: Distribution of the number of fires that affect selected land cover classes (Percentage of overall area characterized by 1 to 12 fire-affected years).

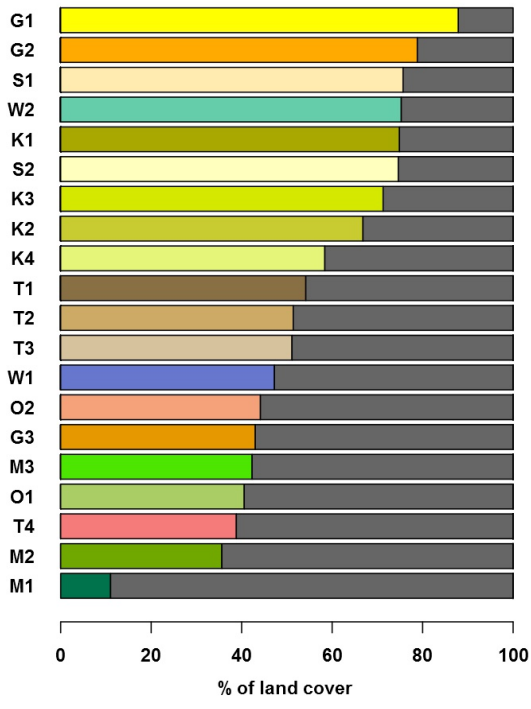

$\square$ fire affected $\square$ not fire affected

Fig. 10: Percentage of non-fire affected and fire affected areas within each major land cover class for the observation period 2001 to 2012.

different. A model inversion can only be attempted if at least seven observations are available (Justice et al. 2006); hence a prolonged period of cloudy conditions hampers the viability of this method. Nevertheless, the analysis of AF fire seasonality (Fig. 4), which is surely not contaminated by a high percentage of missing data, clarifies that fires rarely occur within the rain season. Contrary, invalid observations in BA are mainly bound to the wet season (Fig. 7). Thus it is unlikely that there are many fires which were not detected by the BA product in the area under investigation as a cause of missing data. Figure 7 also illustrates that the number of invalid observations decreases rapidly after the commissioning of MODIS onboard Aqua, which is due to the increased sampling frequency. As a result, the number of cases decreases where less than 7 observations are available to invert the BRDF model.

\section{Comparison of AF und BA products}

As mentioned before the $\mathrm{AF}$ and $\mathrm{BA}$ product are based on independent methodologies which are causing differences in the registered fire extent and consequently, fire frequency. Figure 8 exemplifies the difference of the products based on data from September 2008. The RGB-composite of Landsat TM/ETM+ data shows the near infrared reflectance (NIR, band 4) from September $13^{\text {th }}$ (red), $21^{\text {st }}$ (green) and $29^{\text {th }}$ (blue) and displays the areas that have burned within the respective period. Thereby, the striped pattern within the image results from the scan line error of Landsat ETM+ (SLCoff data). Dark grey to black areas have burned before September $13^{\text {th }}$, red coloured areas between September $13^{\text {th }}$ and $21^{\text {st }}$ and yellow coloured areas between September $21^{\text {st }}$ and $29^{\text {th }}$. The BA product captures the fire extent very well whereas the AF product is fragmentary. This results from the snapshot-like detection of the fire fronts and partly from considering only fires that were labelled as highly confident which also applies for the BA product. Both products allow for a detailed analysis of the dates of the fire events and the expansion of the fire fronts. As our study focuses on an overall description of the fire regime for the Okavango Catchment detailed temporal information was discarded. FRP shows a discontinuous pattern of low and high intensity fire fronts that depends on many factors. A detailed interpretation of the pattern would require information about e.g. the fuel load, water content of the fuel, local weather conditions and the heat yield etc.

\section{Fire regime and land cover}

The BA fire frequency was intersected with the land cover information to understand if land cover strata are affected differently by fire. Figure 9 illustrates the mean annual rate of pixels affected by fires per land cover class and Figure 10 shows the percentage of the overall area per land cover class that was affected by fire within the observation period. Figure 9 shows that based on the BA observations Miombo woodlands (M1, M2, M3) in the north-eastern part of the catchment are least impacted by fires.

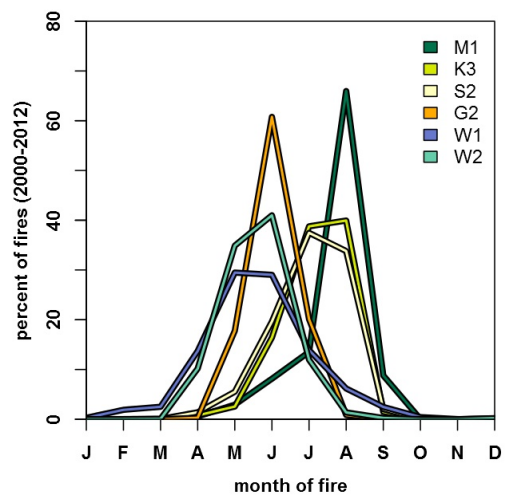

Fig. 12: Percentage of the overall detected fires per month. 


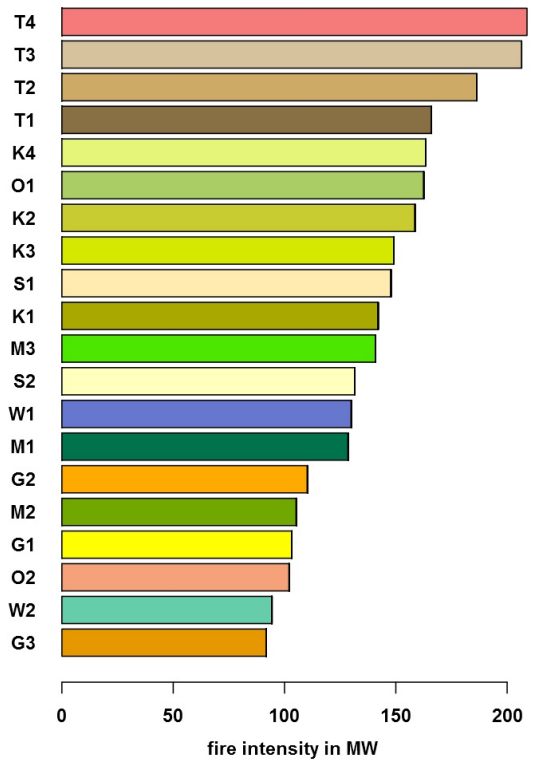

Fig. 13: Mean fire intensity of fires detected within the major land cover strata.

Especially, the grasslands (G1, G2) as well as the peatlands (W2) in the upper catchment areas are highly fire affected as well as the shrublands (S1, S2) and woodlands on Kalahari sand $(\mathrm{K} 1, \mathrm{~K} 2)$. Whereas only $10 \%$ of the overall area of Miombo woodlands with Cryptosepalum exfoliatum (M1) has been affected by fire at least once during the observation period (Fig. 10), fires were observed in more than $80 \%$ of the fluvial valleys in the upper catchment covered by grasslands (G1, G2).

In this context it is also of interest to analyse how often fires were observed for each pixel in the various land cover classes. Figure 11 illustrates the distribution of fire frequency in relation to the overall area for selected land cover classes. The diagram nicely depicts that most of the Miombo woodlands (M1) that were fire affected have only burned once or twice during the 12 years of observation. The same is true for the areas which are flooded more or less permanently (W1). The Miombo woodlands (M1) are characterised by a quite dense tree cover. With increasing tree cover fire disposition is reduced significantly as grass and shrubs, which are more prone to fire and are the main components of fire fuel, are repressed. Therefore, fire frequency and extent is much lower compared to areas where grass and shrubs are dominating like for instance in the savannah areas and the river valleys of the upper catchment. Miombo woodlands are very sensitive to fire and tree biomass and cannot be sustained if annual fires occur (Ryan and Williams 2011). Consequently, a changing fire regime might have major impacts upon the Miombo woodlands. In this context it is also important to consider the limits of the fire products provided by MODIS. Fires are often confined to the grass and shrub layer and do not affect tree crowns (le Roux 2011). As tree cover of Miombo woodlands is often quite high it is possible that fires are not detected as they are disguised by the crown cover. Nevertheless, tree cover densities below $60 \%$ should not hinder the detection of fires in savannahs by remote sensing data (Fuller et al. 1997, Pereira, 2003) and even tree covers of more than $60 \%$ might still allow the detection of fires (Pereira, 2003). Considering research results stating that fire seldomly occurs in savannahs with more than $40 \%$ tree cover (Archibald 2010) we conclude that in our study fire detection in the Miombo woodlands can be regarded as reliable.

In contrast to the Miombo woodlands major parts of the Cryptosepalum maraviense grasslands (G2) and peatlands (W2) are observed to burn almost every year. The fire frequency of the peatlands may be overestimated due to their mingling with other land cover types such as grasslands. Also the vegetation types in the savannah regions of northern Namibia and southern Angola (e.g. open Baikiaea-Burkea-woodlands, $\mathrm{K} 3$ and open shrublands, S2) are frequently affected by fire within the 12 year observation period. Thereby, on a percentage basis, shrublands are more frequently prone to fire than woodlands. This general distribution of fire-affected areas per land cover class is in accordance to studies related to the fire regime in Southern Africa (Pereira, 2003, Archibald, 2010, le Roux 2011).

Figure 12 summarizes the percentage of the overall detected fires that have occurred in each month. The diagram clearly shows that the main fire months are very distinct for the selected land cover classes. Fires in the open vegetation types of the fluvial valleys in the upper catchment occur mainly in May to June whereas the shrub- and woodlands on Kalahari sands are characterised by a fire season from June to August, with maxima in July and August. Fire season in the Miombo woodlands lasts from July to September whereas fires in the inundated Delta areas occur mainly from February to July.
Gradients with respect to the start and length of the rainy season interfere here with the use of fire in land management. In the northern part of the catchment, open grass- and shrublands are burnt early in the dry season (May to June) to initiate regrowth of perennial grasses for cattle grazing and to facilitate hunting. The undergrowth of the Miombo woodlands in this area is still rather humid at this time and does not catch fire easily. However, the preparation of new fields already starts at the end of the rainy season with the slashing of trees. At the end of the rainy season (starting in July and peaking in August), the trunks and branches on the fields are dry enough to be burned and the higher ambient temperatures at this time facilitate the spreading of wildfires to the surrounding woodlands.

In contrast, fires in the drier woodlands at the southern parts of the catchment do not show this bimodal seasonal pattern. Wildfires start in this area once the vegetation is dry enough (June) and gain in frequency and intensity with progressing dry season, peaking in August and ending in October with the first rainfalls.

Figure 13 shows the mean fire intensity for fire-affected areas of each land cover class. Mean fire intensities seem to follow a North-South gradient. Hence, highest mean fire intensities can be found in the savannah regions in the southern part of the study area whereas lower fire intensities appear in the upper catchment area. Fire intensity is very complex and depends on three main factors which are the heat yield of the fuel, spread rate of the fire and the consumed fire fuel (le Roux, 2011). The most important factor is the spread rate, which depends on many factors including conditions of the fuel itself like for instance moisture content (declining with decreasing total precipitation southwards) and fuel type as well as external factors like ambient temperature and wind speed.

Other factors that influence fire intensities include the annual rainfall amount, the length of the dry season and the land cover (cover and distribution of grass, shrubs, and trees). A sufficient amount of rainfall is necessary to produce enough biomass that can serve as fire fuel and the dry season has to endure long enough to support the accumulation of dry flammable fire fuel. During the course of the dry season moisture content decreases and hence dry matter accumulates. At the same time ambient 
temperatures increase (from July onwards). All together this results in rising fire intensities from the beginning to the end of the fire season. This could be one reason for the rather low fire intensities in the grass- and dwarf-shrub dominated vegetation types in the fluvial valleys of the upper catchment that offer little fuel and already burn quite early during the coldest period of the year. Tree cover is another important factor influencing fire intensity. Crown cover fires rarely occur in African savannahs and fires are mostly confined to the grass and shrub layer. A high percentage in canopy cover supports a wetter microclimate which in turn represses the grass and shrub layer in favour of a thick moss and lichen layer. This results in compacted, coarse fuels with a high moisture content and little oxygen supply which has adverse effects on fire intensity (le Roux, 2011). Therefore, the burn fuel is not as easily flammable as fine fuels composed of dried grass and shrubs as present in the savannah and woodland land cover classes. Despite its high percentage of foliage, drought-induced littering is also less prominent in dense Crpytosepalaum forests as the wet microclimate supports evergreen foliages which in turn prevent the accumulation of a flammable hard-dried litter layer. However, the transformation of single stemmed Miombo woodlands to multistemmed shrublands after shifting cultivation or charcoal production enhances the available amount of fuel close to the ground and tends to produce more intense fires. Land use change with progressing shifting cultivation may thus push the original Miombo ecosystems towards higher fire frequencies and intensities with the corresponding impacts on carbon dioxide emissions at the macro-regional level.

\section{Conclusions}

The available MODIS fire products provide a clear picture of important fire regime descriptors. Whereas both products capture a similar seasonality of the fire regime the BA product can be regarded as more reliable concerning the extent of fires and thus, the fire frequency. However, only AF allows insights into fire intensity.

The combination of MODIS fire products with phenology-based land cover analyses allows for ecosystem sensitive and spatially explicit analyses of fire patterns and fire risks in terms of wildfire frequencies, seasonal fire dynamics and fire intensities. Regional differences in fire dynamics follow climate and vegetation gradients: fires in the upper catchment start in June/July whereas in the middle reaches and the delta fires chiefly occur in August and September. As fires are mostly manmade, the burning seasonality corresponds to the agricultural practices in the different seasons. Moreover, the north-eastern part of the catchment is less densely populated which may also be a reason for lower fire frequencies compared to other areas. Fire intensities are higher in central parts and open vegetation types are more affected by fire than for example the comparatively closed Miombo woodlands of the Angolan central plateau.

The transformation of land cover classes by agricultural expansion (e.g. Miombo to field to shrubland) may change fire dynamics, with the corresponding consequences for ecosystems and their services.

Future work will comprise analyses of spatial as well as inter-annual variations of the fire regime within land cover classes for instance by analysing phenological metrics and weather conditions. Frost et al. (1996) stated that understanding such interactions is probably one key element understanding Miombo woodland dynamics. Thus, it will be important to gain a deeper understanding of the interactions and consequences of the fire regime and possible changes for ecosystems in the Okavango Catchment area. Moreover, a better understanding of fire intensity, which would require knowledge about understory fuel load and heat yield, would provide further important information for characterising the fire regime. A combination of the $\mathrm{BA}$ and $\mathrm{AF}$ products as well as the integration of data from other sensors (e.g. METEOSAT) may further enhance the capability to describe components of the fire regime in the Okavango region.

\section{Acknowledgements}

"The Future Okavango" project is funded by the German Federal Ministry of Education and Research (BMBF) in the frame of the funding measure "Sustainable Land Management". This support is gratefully acknowledged. The authors would also like to thank the NASA, the U.S. Geological Survey and the University of Maryland for providing the imagery, which were essential for this study. The authors wish to thank two reviewers for providing helpful comments and suggestions that greatly helped to improve the manuscript.

\section{References}

Anderson, A.N., Cook, G.D., Williams, R.J. (2003): Fire in Tropical Savannas. New York: Springer. CrossRef

Andrae, M.O. (1997): Emissions of trace gases and aerosols from southern African savanna fires. In: R.W. Van Wilgen, M.O. Andreae, J.G. Goldammer and J.A. Lindesay [Eds.]: Fire in Southern African Savannas: Ecological and atmospheric perspectives 161-184. Johannesburg: Witwatersrand University Press.

Archibald, S. (2010): Fire Regimes in Southern Africa - Determinants, Drivers and Feedbacks. - PhD thesis. University of the Witwatersrand, Johannesburg.

Bond, W.J., Keeley J.E. (2005): Fire as a global "herbivore": the ecology and evolution of flammable ecosystems. Trends in Ecology and Evolution 20(7): 387-394. CrossRef

Chidumayo, E.N. (1995): Handbook of Miombo Ecology and Management. Stockholm Environment Institute.

Clark, D. and Van Zinderen Bakker, E.M. (1964): Prehistoric culture and pleistocene vegetation at the Kalambo Falls, Northern Rhodesia. - Nature 201: 971-975. CrossRef

Davies, D.K., Ilavajhala, S., Wong, M.M., Justice, C.O. (2009): Fire Information for Resource Management System: Archiving and Distributing MODIS Active Fire Data. - IEEE Transactions on Geoscience and Remote Sensing 47 (1): 72-79. CrossRef

De Sy, V., Herold, M., Achard, F., Asner, G.P., Held, A., Kellndorfer, J., Verbesselt, J. (2012): Synergies of multiple remote sensing data sources for REDD+ monitoring. - Current Opinion in Environmental Sustainability 4(6): 696-706. CrossRef

Dwyer, J., Weiss, J., Schmidt, G., Logar, T., Burrel, R., Stubbendieck, G., Rishea, J., Misterek, B., Jia, S., Heuser, K. (2001): The MODIS Reprojection Tool. American Geophysical Union, Spring Meeting 2001, abstract \#U21A-24.

Frost, P. (1996): The ecology of miombo woodlands. - In: Campbell, B. (ed), The Miombo in Transition: Woodlans and Welfare in Africa. Center for International Forestry Research (CIFOR), 11-55.

Fuller, D.O., Prince, S.D., Astle, W.L. (1997): The influence of canopy strata on remotely sensed observations of 
savanna-woodlands. - International Journal of Remote Sensing 18(14): 2985-3009. CrossRef

Giardina, C.P., Sanford Jr., R.S., Døckersmith, I.C., Jaramillo, V.J. (2000): The effects of slash burning on ecosystem nutrients during the land preparation phase of shifting cultivation. - Plant and Soil 220: 247-260. CrossRef

Giglio, L., Descloitres, J., Justice, C.O., Kaufman, Y.J. (2003): An Enhanced Contextual Fire Detection Algorithm for MODIS. - Remote Sensing of Environment 87: 273-282. CrossRef

Giglio, L. (2010): MODIS collection 5 active fire product user's guide - Version 2.4. University of Maryland: College Park, MD.

Govender, N., Trollope, W.S.W., Van Wilgen, B.W. (2006): The effect of fire season, fire frequency, rainfall and management on fire intensity in savanna vegetation in South Africa. Journal of Applied Ecology 43: 748-758. CrossRef

Huete, A., Didan, K., Miura, T., Rodriguez, E.P., Gao, X., Ferreira, L.G. (2002): Overview of the radiometric and biophysical performance of the MODIS vegetation indices. - Remote Sensing of Environment 83: 195-213. CrossRef

Ichoku, C., Kaufman, Y.J. (2005): A method to derive smoke emission rates from MODIS fire radiative energy measurements. - IEEE Transactions on Geoscience and Remote Sensing 43: 2636-2649. CrossRef

Jönsson, P., Eklundh, L. (2002): Seasonality extraction by function fitting to time-series of satellite sensor data. IEEE Transactions on Geoscience and Remote Sensing 40(8): 1824-1832. CrossRef

Justice, C., Giglio, L., Boschetti, L., Roy, D., Csiszar, I., Morisette, J., Kaufman, Y (2006): MODIS fire products - Version 2.3. Algorithm Technical Background Document.

Korontzi, S., McCarty, J., Loboda, T., Kumar, S., Justice, C.O. (2006): Global distribution of agricultural fires in croplands from 3 years of Moderate Resolution Imaging Spectroradiometer (MODIS) data. - Global Biogeochemical Cycles 20: GB2021. $\underline{\text { CrossRef }}$

Laris, P. (2005): Spatiotemporal problems with detecting and mapping mosaic fire regimes with coarse-resolution satellite data in savanna environments. Remote Sensing of Environment 99: 412-424. CrossRef

le Roux, J. (2011): The effect of land use practices on the spatial and temporal characteristics of savanna fires in Namibia. PhD dissertation, FriedrichAlexander-Universität ErlangenNürnberg, Germany.

Maier, S.W., Russell-Smith, J., Edwards, A.C., Yates, C. (2013): Sensitivity of the
MODIS fire detection algorithm (MOD14) in the savanna region of the Northern Territory, Australia. - ISPRS Journal of Photogrammetry and Remote Sensing 76: 11-16. CrossRef

Penman, J., Gytarsky, M., Hiraishi, T., Krug, T., Kruger, D., Pipatti, R., Buendia, L., Miwa, K., Ngara, T., Tanabe, K., Wagner, F. (2003): Good Practice Guidance for Land Use, Land-use Change and Forestry. IPCC National Greenhouse Gas Inventories Programme and Institute for Global Environmental Strategies, Kanagawa, Japan.

Pereira, J.M.C. (2003): Remote sensing of burned areas in tropical savannas. International Journal of Wildland Fire 12: 259-270. CrossRef

Roy, D.P., Lewis, P.E., Justice, C.O. (2002): Burned area mapping using multi-temporal moderate spatial resolution data - a bi-directional reflectance model-based expectation approach. - Remote Sensing of Environment 83: 263-286. CrossRef

Roy, D.P., Jin, Y., Lewis, P.E., Justice, C.O. (2005a): Prototyping a global algorithm for systematic fire-affected area mapping using MODIS time series data. - Remote Sensing of Environment 97: 137-162. CrossRef

Roy, D.P., Frost, P.G.H., Justice, C.O., Landmann, T., le Roux, J.L., Gumbo, K., Makungwa, S., Dunham, K., Du Toit, R., Mhwandagara, K., Zacarias, A., Tacheba, B., Dube, O.P., Pereira, J.M.C., Mushove, P., Morisette, J.T., Santhana Vannan, S.K., Davies, D. (2005b): The Southern Africa Fire Network (SAFNet) regional burned-area product-validation protocol. International Journal of Remote Sensing 26(19): 4265-4292. CrossRef

Roy, D.P., Boschetti, L., Justice, C.O., Ju, J. (2008): The collection 5 MODIS burned area product - Global evaluation by comparison with the MODIS active fire product. - Remote Sensing of Environment 112: 3690-3707. CrossRef

Ryan, C. M., Williams, M. (2011): How does fire intensity and frequency affect miombo woodland tree populations and biomass? - Ecological Applications 21: 48-60. CrossRef

Sá, A.C.L., Pereira, J.M.C., Silva, J.M.N. (2005): Estimation of combustion completeness based on fire-induced spectral reflectance changes in a dambo grassland (Western Province, Zambia). - International Journal of Remote Sensing 26(19): 4185-4195. CrossRef

Stronach, N.R.H., McNaughton, S.J. (1989): Grassland Fire Dynamics in the Serengeti Ecosystem, and a Potential Method of Retrospectively Estimating Fire Energy. - Journal of Applied Ecology 26(3): 1025-1033. CrossRef

Trapnell, C.G. (1959): Ecological results of woodland burning experiments in Northern Rhodesia. - Journal of Ecology 47: 129-168. CrossRef

Van Langevelde, F., van de Vijver, C.A.D.M., Kumar, L., van de Koppel, J., de Ridder, N., van Andel, J., Skidmore, A.K., Hearne, J.W., Stroosnijder, L., Bond, W.J., Prins, H.H.T., Rietkerk, M. (2003): Effects of fire and herbivory on the stability of savanna ecosystems. Ecology 84(2): 337-350. CrossRef

Vermote, E., Ellicott, E., Dubovik, O., Lapyonok, T., Chin, M., Giglio, L. and Roberts, G.J. (2009), An approach to estimate global biomass burning emissions of organic and black carbon from MODIS fire radiative power. Journal of Geophysical Research 114: D18205. CrossRef

Wooster, M.J., Roberts, G., Perry, G.L.W. (2005): Retrieval of biomass combustion rates and totals from fire radiative power observations: FRP derivation and calibration relationships between biomass consumption and fire radiative energy release. - Journal of Geophysical Research 110: D24311. CrossRef

\section{Affiliations}

Marion Stellmes* (stellmes@unitrier.de), David Frantz (frantz@unitrier.de), Achim Röder (roeder@unitrier.de), Joachim Hill (hillj@uni-trier.de) Department of Environmental Remote Sensing and Geoinformatics, Faculty of Regional and Environmental Sciences University of Trier 54286 Trier, GERMANY

Manfred Finckh (manfred.finckh@unihamburg.de), Rasmus Revermann (rasmus.revermann@uni-hamburg.de) Biodiversity, Evolution and Ecology of Plants, Biocentre Klein Flottbek and

Botanical Garden

University of Hamburg

Ohnhorststr. 18

22609 Hamburg, GERMANY

*Corresponding author 